\title{
ASTHA BRATA DAN PRANATA MANGSA: ALAM DAN RELASI KUASA DALAM KONTEKS AGRARIA DI JAWA
}

\author{
Nina Witasari \\ Jurusan Sejarah, Fakultas Ilmu Sosial, Universitas Negeri Semarang \\ nina.witasari@yahoo.com
}

\begin{abstract}
The presence of the ruler and its authority in people's daily life is an interesting talk especially when it is related to welfare case. The understanding of the meaning of authority relation is manifested into government leadership practice, which at the same time, is connected to concern on maintaining the balance of nature. Based on the phenomena existence, this writing discusses about the problem of people's authority relation position as exploitation object by the King in pactice. Does people accept their position and authority relation as necessity since they were born as servant. Or, instead, through people's resignation accepting their destiny, they become more creative emerging local wisdom and knowledge based on environment. At this same time, people apply work management system called season regulation 'pranatamangsa'. Pranatamangsa is manifestation of harmonious relation among human being - nature - God. Javanese farmer has faith that, like any other traditional ethnic people, the way God does arrange the nature is through the nature's sign, as part of cosmological balance.
\end{abstract}

Key words: authority relation, pranatamangsa, cosmological balance.

\begin{abstract}
ABSTRAK
Kehadiran penguasa dan kekuasaannya dalam keseharian kehidupan rakyatnya adalah hal yang menarik untuk dibicarakan terutama bila dihubungkan dengan kesejahteraan. Pemahaman tentang relasi kuasa di sini adalah yang termanifestasi dalam praktek kepemimpinan pemerintahan, yang pada saat yang sama, tersambung dengan kepedulian untuk menjaga keseimbangan alam. Berdasarkan fenomena yang ada, problematika yang ingin dibahas dalam tulisan berikut ini adalah bagaimana relasi kuasa rakyat yang dalam prakteknya diposisikan sebagai obyek eksploitasi oleh Raja. Adakah rakyat menerimanya sebagai sebuah keniscayaan atas kelahiran mereka sebagai kawula. Ataukah justru dalam kepasrahan menerima garis nasib mereka justru menjadi lebih kreatif dengan memunculkan kearifan dan pengetahuan lokal berbasis lingkungan. Pada saat sama, dalam masyarakat berlaku sistem pengaturan kerja yang disebut pranata mangsa. Pranata mangsa merupakan wujud harmonisasi hubungan antara manusialingkungan alam-dan Tuhan Yang Maha Esa. Keyakinan petani Jawa, dan masyarakat tradisional pada etnis lain, adalah bentuk keyakinan atas cara Tuhan bekerja mengatur alam melalui tanda-tanda alam, sebagai bagian dari keseimbangan kosmologis.
\end{abstract}

Kata kunci: relasi kuasa, pranata mangsa, keseimbangan kosmologis

\section{PENDAHULUAN}

Penguasa dan kekuasaan penting untuk dibahas dalam kaitannya dengan kesejahteraan rakyat. Yang tidak kalah pentingnya, mengkaitkan hal-hal itu dengan keseimbangan ekosistem. Menarik untuk dicatat bahwa kehirauan tentang hal itu kembali mengemuka, seiring makin tingginya kesadaran untuk kembali menegakkan prinsipprinsip kesejatian pemerintahan. Urgensi membahas hal itu semakin terasa ketika disadari bahwa konsepsi tentang kekuasaan tersebut sebetulnya teraktualisasi secara nyata meskipun tidak ke- 
hadirannya tidak selalu kasat mata. Konsepsi tentang kekuasaan ternyata memiliki arti penting untuk persoalan yang seakan berada di luar diskusi akademik.

Hal yang hendak dibahas di sini adakah konseptualisasi tentang kekuasaan dalam alam fikir Jawa. Kalaulah tulisan ini tersaji, bukanlah berarti bahwa konsep kekuasaan Jawa lebih unggul dari konsep kepemimpinan dari etnik lain. Pilihan pada peranan dan bekerjanya kekuasan Jawa ini lebih didedikasikan untuk menawarkan pemikiran dan menyelaminya untuk kepentingan tertentu. Yang hendak difahami adalah bagaimana relasi kuasa ini manifest dalam praktek kepemimpinan pemerintahan, yang pada saat yang sama, tersambung dengan kepedulian untuk menjaga keseimbangan alam. Kalaulah kepemimpinan didedikasikan untuk mencapai kesejahteraan umat, cara menempuhnya tetap dalam koridor keseimbangan dengan alam. Telaah tentang praktik kekuasaan yang dilakukan di sini sama sekali tidak dimaksudkan untuk menumbuhkan kembali primodialisme dan kesukuan. Justru dari diskusi ini diharapkan mampu memberi sumbangsih dalam pembentukan kearifan nasional, dengan merespons kemajuan ilmu pengetahuan dan nilai kemanusiaan yang universal.

Salah satu nilai kekuasaan yang termanifestasi dalam kehirauan akan keseimbangan alam ada pada ajaran Astha Brata. Kekuasaan raja Jawa juga telah mengambil manfaat kodifikasi perilaku alam yang dikenal dengan sebutan Pranata Mangsa. Kodifikasi pengetahuan tentang perilaku alam ini di satu sisi mengisyaratkan kecerdasan sekaligus kearifan lokal, dan pada saat yang sama manifest bekerjanya sistem pengetahuan dan representasi kendali terhadap dahsyatnya kekuasaan alam. Di sini jelaslah bahwa tata kuasa ber- langsung secara simultan dengan regularisasi praktek bercocok tanam sesuai musim.

Lebih dari itu, alam juga diposisikan sebagai medium untuk mengekspresikan kekuasaan. Hal tersebut tercermin dalam gelar yang digunakan oleh para raja di Jawa, seperti Sri Susuhunan Pakubuwana, Sri Mangkunegara, Sri Sultan Hamengkubuwana, atau Sri Pakualam. Nama dan gelar tersebut merupakan kombinasi yang menjelaskan posisi penguasa sebagai pemegang kedaulatan wilayah sekaligus menjadi medium pengejawantahan kuasa ilahiah di muka bumi. Raja adalah representasi bekerjanya kekuasaan jagad gedhe atau Macro-cosmos atas jagad cilik atau Microcosmos, melalui prosedur wangsit; sebuah legitimasi non-formal dalam konsep kekuasaan Jawa. Wangsit juga berperan sebagai modal bagi seorang raja untuk mendapatkan posisi kehormatan dalam lingkungan keagamaan, dimana ia memiliki prioritas untuk mendapatkan kekuatan, kasektén, yang memberinya hak untuk menjalankan kekuasaan (Handayani:2004, hlm.103, Anderson: 1972)

Seorang raja dituntut mampu menyeimbangkan tuntutan kesejahteraan ekonomi, keberlangsungan kekuasaan politik dan tetap terjaganya ekosistem. Keseimbangan tersebut dapat diperoleh jika ada sistem pengetahuan yang mendukung, serta teknologi yang menunjang. Tuntutan multi-peran tersebut yang menjadi pematik kemunculan HAstha Brata, sebagai panduan untuk menjadi penguasa yang ideal, ini penting bagi keberlangsungan laju pemerintahan dan jaminan atas langgengnya sebuah kekuasaan politik. Raja, sebagai sang Nata adalah representasi dari perilaku alam, yang tercermin dalam nama dan gelarnya yang mengacu pada fenomena alam, seperti Hamengkubuwana yang berarti 
mengelola bumi, atau Pakualam yang bermakna memantapkan keseimbangan alam.

Dalam kerangka pemahaman tersebut di atas kita bisa memaklumi keterkaitan antara alam, kekuasaan dan kesejahteraan. Guna memastikan terjaminnya kesejahteraan ekonomi, yang dalam konteks ini adalah kerajaan agraris dimana sandaran ekonominya adalah pertanian, maka panduan yang dilahirkan dari rahim pengetahuan tradisional adalah Pranatamangsa. Panduan ini mensyaratkan kepatuhan kepada perilaku ajegnya alam, dengan pemeran utamanya adalah masyarakat kelas bawah, petani. Komunitas terbesar dalam piramida masyarakat kerajaan, yang ditakdirkan sebagai penyangga keberlangsungan hidup lapisan masyarakat diatasnya. Pertanyaan yang perlu diajukan kemudian adalah, bagaimana relasi kuasa rakyat yang dalam prakteknya diposisikan sebagai obyek eksploitasi oleh Raja. Adakah rakyat menerimanya sebagai sebuah keniscayaan atas kelahiran mereka sebagai kawula. Ataukah justru dalam kepasrahan menerima garis nasib mereka justru menjadi lebih kreatif dengan memunculkan kearifan dan pengetahuan lokal berbasis lingkungan.

\section{MENGUNGKAP RELASI KUASA}

Benedict R.O'G. Anderson memang bukan satu-satunya Indonesianist yang aktif mengupas berbagai aspek menyangkut Indonesia. Namun perhatiannya yang fokus terhadap Jawa, membuat namanya selalu menjadi rujukan setiap kali perbincangan tentang konsep kekuasaan yang mendominasi perpolitikan di Indonesia. Itulah juga yang menjadi alasan, mengapa tulisan ini juga merujuk pada pemikirannya. G. Moedjanto adalah javanist yang buah pikiran sangat layak dijadikan rujukan ketika membicarakan konsep kekuasaan raja Jawa. Pilihan untuk mengkomunikasikan keduanya muncul disebabkan adanya pertalian pikiran diantara keduanya, yang tidak hanya membicarakan tentang kuasa raja dan implementasinya, tapi keduanya juga menyinggung bagaimana posisi rakyat sebagai pihak yang dikuasi oleh para penguasa.

Untuk mempertajam kajian tentang kekuasaan Jawa ada pemikiran Fachry Ali dalam bukunya Refleksi $\mathrm{Pa}$ ham Kekuasaam Jawa dalam Indonesia Modern (1986) serta pandangan Soemarsaid dalam Negara dan Usaha Bina-Negara di Jawa Masa Lampau (1986) tentang dasardasar kepemimpinan Jawa. Menurut keduanya Astha Brata memberi panduan sekaligus mengajarkan tentang moral berkuasa, kebajikan-kebajikan yang harus direalisasikan, tantangan-tantangan yang harus dihadapi dan sikap diri yang bijak, senyum dan meluruskan yang bengkok-bengkok, berbuat baik dan bertindak bijaksana kepada rakyat (abdi dalem). Raja dituntut untuk memberikan teladan yang bagus dan menunjukkan rasa perdamaian yang mendalam, sebagai konsekuensi atas otoritas sekuler yang luas, namun sekaligus kekuatan spiritual dan kekuatan sosial. Raja merupakan kekuatan transendental yang berfungsi sebagai soko guru masyarakat yang tugas utamanya menjaga keutamaan nilai-nilai keutamaan Jawa. Apabila raja menyimpang dari Astha Brata dan norma kesusilaan, bukan hanya wibawanya yang, tetapi juga akan menjadi satria wiring (Heri, 2012:1)

Pada orasi ilmiahnya di Simposium Internasional "Antropologi Indonesia" di UI Juli 2005 yang lalu, Hans Antlov menyebut karya Ben Anderson, the Idea of Power in Javanese Culture, sebagai pernyataan paling berpengaruh pada 
konstruksi budaya yang dominan di Indonesia dan banyak orang menggunakannya sebagai titik tolak dalam studi mereka adalah konsep Benedict Anderson " The Idea of Power in Javanese Culture " (1972, dicetak ulang pada tahun 1990). Dimana ia berhasil membuat uraian yang meyakinkan tentang pemikiran politik Jawa dan pengaruhnya terhadap penyelenggaraan negara bahkan di masa modern. Anderson berpendapat bahwa konsep kekuasaan Jawa (kasektén) lebih dekat dengan potensi spiritual daripada ideide Eropa tentang kekuasaan relasional. Hal tersebut bertentangan dengan ideide Barat, yang menyatakan bahwa kasektén ini adalah "sesuatu yang konkret, homogen, konstan dalam jumlah total dan tanpa implikasi moral yang melekat" (Anderson 1972:8). Kekuasaan dapat dimiliki dan dilakukan oleh orang per-orang, tetapi tidak pernah dibuat atau diubah oleh mereka. Kekuatan spiritual mengalir dari pusat memancar dan menyebar seperti lingkaran di atas air, atau seperti kerucut cahaya dibiaskan oleh lampu reflektor. Hubungan antara pemerintah dan yang diperintah ditandai dengan hubungan yang disebut patronase.

The administrative structure, while formally hierarchical, is in effect composed of stratified clusters of patron client relationships. Both in the regions and in the centre, officials gather around them clusters of personal dependents, on the model of the ruler himself. These dependents " destinies are linked with the success or failure of their patrons. They work as administrative and political aides, and have no real autonomous status except in relation to him (Anderson 1972:22).

G. Moedjanto dalam analisanya, Konsep Kekuasaan Jawa Penerapannya oleh Raja-Raja Mataram (1987) kemudian memberikan tekanan bahwa konsep kekuasaan raja yang absolut tergambar dalam simbol Gung binathara bau dhenda hanyakrawati, berkuasa atas dunia bagai dewa (bathara) dan memelihara keberlangsungan hukum. Jelas di sini bahwa ada posisi rangkap seorang raja, sebagai pihak eksekutif, legislatifsekaligus judikatif. Sekali lagi yang harus diingat adalah bahwa tidak ada distribusi kekuasaan dalam konsep kekuasaan Jawa. Konsep kekuasaan Jawa yang digunakan oleh raja-raja Mataram diturunkan dari dua sumber, yakni ajaran Hindu dan Islam. Hal ini nampak dari beberapa istilah dan penanda yang masih menggunakan unsur Hindu dan sebagian lagi menunjukkan pengaruh Islam. Kata binathara yang berasal dari akar kata bathara yang berarti dewa, jelas menunjukkan pengaruh Hindu. Selain itu kata hanyakrawati yang mempunyai unsur kata cakra yang berarti senjata dewa Wisnu, memberi bukti lain tentang pengaruh Hindu. Sedang pengaruh Islam nampak dalam rangkaian gelar yang digunakan oleh penguasa, seperti kata Sultan, atau Khalifatullah panatagama. Selain itu pengaruh Islam juga nampak pada bacaan-bacaan yang dilafalkan dalam tiap upacara ritual di lingkungan keraton (Moedjanto, 1987:122)

Hal yang tidak kalah menarik adalah penjelasan Moedjanto tentang bagaimana garis keturunan berperan besar dalam mengamankan sebuah kedudukan. Silsilah keluarga penguasa yang disusun atas dasar pemberitaan dalam babad. Dalam hal ini sangat tampak bahwa prinsip trahing kusuma, rembesing madu, wijining atapa, tedhaking andana warih sangat dijaga oleh para penguasa Jawa. Konsep ini berarti bahwa orang-orang yang menduduki jabatan atau kekuasaan tertentu haruslah memiliki syarat asal-muasal orang tuanya. Penyusunan garis keturunan dari seorang penguasa yang bersumber dari babad, memang sarat dengan kepen- 
tingan politis, karena hal ini berkaitan erat dengan pengamanan kekuasaan. Bahkan agar nampak dahsyat, seringkali penarikan jalur keturunan mengawinkan antara keturunan dewa; yang notabene adalah konsep Hindu; dengan keturunan nabi; yang merupakan unsur Islam (Moedjanto, 2002:129).

Belum lagi penggunaan bahasa Jawa yang menganut hirarki dan strata, yang menurut Moedjanto adalah alat politik yang sengaja diciptakan oleh penguasa untuk menegaskan perbedaan strata dan status antara kelas bangsawan dan rakyat kebanyakan. Tidak hanya itu, dalam lingkungan keratonpun diketahui ada penggunaan bahasa jawa khusus, yang disebut Bagongan, tujuannya tidak lain adalah untuk makin memberi jarak antara lingkungan keraton dengan luar keraton, dan untuk menumbuhkan kesan kesakralan lingkungan kerajaan, tetapi selain itu ternyata juga karena alasan keamanan. (Moedjanto, 1994:61)

Baik pengamatan Anderson maupun analisis Moedjanto nampaknya saling melengkapi pemahaman kita mengenai bagaimana kekuasaan Jawa terbentuk, berfungsi dan dilanggengkan. Keberlangsungannya sangat didukung oleh kemapanan sebuah sistem, dan keberhasilan menanamkan ideologi dalam tiap kepala komunitas pendukungnya dalam hal ini orang Jawa. Namun demikian, ada hal-hal yang tidak terungkap dan terdeskripsikan dengan jelas dalam kajian Anderson maupun Moedjanto mengenai konsep kekuasaan, yaitu bagaimana rakyat diposisikan dalam konstelasi besar ini. Adakah mereka berada jauh diluar sistem tersebut ataukah memang sistem yang tidak memberikan celah sedikitpun bagi rakyat untuk memperbaiki posisi tawarnya. Meskipun Anderson maupun Moedjanto tidak memberikan tukikan yang tajam tentang hal tersebut, dalam beberapa bagian mereka menyebutkan bagaimana posisi kawula berperan dalam konstelasi kuasa seorang raja. Istilah-istilah seperti jumbuhing kawula lan gusti atau ndherek kersa ndalem menunjukkan bagaimana rakyat diposisikan. Kondisi tersebut makin diperkuat dengan munculnya konsep hubungan kawula lan gusti, yaitu: (1) Suatu hubungan yang erat disertai dengan rasa saling mencintai dan menghormati sebagai dasar komunikasi sosial; (2) Nasib menentukan kedudukan seseorang dalam masyarakat, manusia tidak mempunyai pilihan tetapi harus memikul kewajiban seperti yang telah ditentukan oleh nasibnya; (3) Raja dan pegawainya, dalam hal pemerintahan, harus memperhatikan rakyatnya (Moertono:1985).

Namun demikian justru inilah yang kemudian membukakan peluang untuk makin menggali apa yang selama ini terlewatkan dalam mengupas konsep kekuasaan jawa, yaitu ketidakhadiran rakyat dalam ruang kekuasaan, yang pastilah didesign sedemikian rupa melalui sistem yang sangat rapi dan terjaga.

\section{SISTEM KEKUASAAN RAJA JAWA}

Raja dalam pandangan dunia Jawa mempunyai kekuasaan absolut yang dilegitimasi oleh kekuatan ilahi. Istilah yang dipakai untuk menggambarkan sifat-sifat raja adalah gung binatara, sekti mandraguna, bahudhendha hanyakrawati yang artinya agung bagai dewa, sakti luarbiasa, penguasa ruang dan waktu kiranya menunjukkan pandangan dunia orang Jawa terhadap kekuasaan seorang raja. Sebagai penguasa ruang dan waktu, tidak ada yang dapat terlewat dari aliran kekuasaan seorang raja, sehingga kekuasaan dalam pandangan dunia Jawa selalu tunggal, homogen dan masif. 
Predikat bahudhendha mengandung kata bahu yang artinya ukuran keluasan dalam ruang, sementara hanyakrawati mengandung pengertian cakra, yang artinya waktu. Maka istilah bahudhendha hanyakrawati dapat dimaknai sebagai penguasa ruang dan waktu. Perbandingan yang sesuai dengan istilah tersebut adalah interpretasi G. Moedjanto dalam Hans Antlov dan Sven Cederroth (ed), (2001).

Sebagai panduan dalam melaksanakan perannya sebagai pemimpin, Raja Jawa menyandarkan model idealnya pada ajaran Astha Brata, yaitu delapan sifat yang harus dimiliki oleh seorang pemimpin dan dalam kasus ini adalah Raja. Seorang raja harus mempunyai sifat-sifat Bumi, Matahari, Bulan, Bintang, Api, Air, Angin dan Samudera. Kedelapan sifat tersebut merupakan simbolisasi dari sifat-sifat Kesejahteraan, Semangat kerja, Solusi, Pemandu arah, Menjaga kesucian, Rendah hati, Cermat dan Waspada, serta Menampung tanpa pamrih dan tanpa pilih. Terlepas dari makna yang terkandung dari tiap simbol tersebut, kita dapat melihat bahwa simbol yang dipilih adalah bagian dari alam lingkungan. Tentunya hal ini tidak terlepas dari kenyataan bahwa kerajaan yang menganut paham Astha Brata adalah kerajaan berbasis agraria. Kerajaan agraria biasanya menyandarkan kelangsungan hidupnya pada usaha pertanian, yang diusahakan di wilayah-wilayah pedesaan. Dengan demikian sesungguhnya desa dan petani adalah tulang punggung keberlangsungan kekuasaan sang Raja, melalui struktur birokrasi vertikal yang sengaja dibangun dan dikukuhkan.

Sebenarnya ada sejumlah konsep kepemimpinan Jawa yang diproduksi dalam banyak bentuk, salah satunya berbentuk Serat, seperti Serat Sastra Gendhing peninggalan Sultan Agung, atau pun Serat Wulang Jaya Lengkara. Keduanya sarat dengan ajaran yang mulia, bagaimana seharusnya seorang Raja berwatak, bersikap dan berperilaku sesuai yang digariskan dalam ajaran, sebagai model ideal seorang penguasa Jawa. Maka jika diperhatikan dengan seksama, baik Astha Brata, Serat Sastra Gendhing maupun Serat Wulang Jaya Lengkara, kesemuanya menempatkan posisi Raja sebagai penguasa yang berhak atas segala penghormatan, kesetiaan dan kepatuhan dari masyarakat yang dipimpinnya. Lebih jauh, serat membangun konstruksi pandang bahwa segala aspek kepemimpinan Raja adalah pengejawantahan kuasa Tuhan di dunia. Dan sekali lagi dalam interpretasinya ketiganya juga mengambil setting alam dan lingkungan dalam persimbolannya, yang mana makin mengokohkan pemahaman bahwa kekuasaan Raja (Jawa) atas alam bersifat absolut.

Dalam pandangan dunia Jawa, kekuasaan bukanlah hasil sebuah relasi antar individu dengan individu lain atau kelompok, tapi lebih dari itu, ia adalah kekuatan energi ilahi yang meresapi seluruh kosmos dan memiliki eksistensi dalam dirinya sendiri. Kekuasaan bersifat metaempiris dan menyatu dengan hakikat alam semesta, untuk kemudian memusat pada seseorang yang dianggap layak dan patut menyandangnya. Inilah yang kemudian di sebut sebagai Wahyu ratu dan wangsit, dimana berperan besar dalam legitimasi kekuasaan seorang raja Jawa. Wahyu ratu bermakna ijin dari Tuhan yang melegitimasi seseorang untuk berkuasa atas rakyat, sekaligus ia harus bisa meyakinkan penguasa lama untuk tunduk kepadanya, baik lewat jalan damai maupun peperangan. Wangsit adalah petunjuk dari Tuhan berisi halhal yang akan terjadi di masa depan. Oleh sebab itu, posisi raja dalam pan- 
dangan dunia orang Jawa, adalah pusat kosmos sekaligus pusat kekuasaan (Kresna: 2013).

Ketika membahas aspek kekuasan raja Jawa, ada banyak refensi yang muncul justru dari penulis dan peneliti asing. Salah satunya adalah Benedict Richard O'Gorman Anderson yang memberi penegasan bahwa kuatnya konsep kekuasaan para Raja Jawa menyebabkan kultur patriomonial masih kuat melekat pada para pemimpin negeri di Indonesia. Jika kekuasaan itu dipahami sebagai sesuatu yang konkret, maka para pemimpin dan penguasa dianggap sebagai patron yang secara otomatis harus diterima oleh anggota masyarakat sebagai atasan bagi para kliennya. Selain itu kekuasaan politik dan pemerintahan yang dipegang penguasa dianggap sebagai haknya secara alamiah, bahkan kekuasaan tersebut diyakini sebagai sesuatu yang tidak ada sangkut pautnya dengan pemberi kekuasaan yaitu anggota masyarakat. Penegasan Ben yang berikutnya adalah soal homogenitas sumber kekuasaan. Pemahaman terebut berangkat dari konsep berpikir bahwa raja bukanlah manusia biasa, ia adalah manusia yang dikarenakan keturunannya bagaikan dewa atau wakil dari dunia gaib. Yang perlu disadari adalah bahwa, dalam alam berpikir orang Jawa, kekuasaan tidak mengenal sah atau absah. Legitimasi homogenitas sebagai model legitimasi kekuasaan membuka peluang bagi penguasa untuk menjalankan kekuasaannya melampaui penilaian moralitas (Anderson: 1977).

Kekuasaan Raja juga nampak dalam kehidupan alam. Apabila semua elemen dalam kerajaan tersebut tentram, maka alam pun akan memberikan timbal balik yang sesuai, seperti tanah yang subur, keberhasilan panen, dan lain sebagainya. Kondisi ideal seperti itu dapat dicapai apabila ada sarana dan prasarana yang mendukung, seperti teknologi pertanian yang memadai, sistem irigasi, penanggulangan serangan hama dan penanganan pasca panen. Prasyarat tersebut seharusnya menjadi tanggung jawab penguasa, akan tetapi dalam prakteknya semua beban produksi diserahkan kepada petani sebagai penggarap tanah. Baru jika terjadi ancaman terhadap keamanan dan ketertiban yang dapat mempengaruhi kelancaran penyerahan hasil bumi kepada kerajaan, maka penguasa akan turun tangan. Bahkan apabila gangguan tersebut dalam skala besar, bukan tidak mungkin akan terjadi semacam upaya penumpasan terhadap usaha-usaha $\mathrm{kra}$ man tersebut. Apabila hal itu masih terjadi, ataupun masih ada kekuatankekuatan kosmis yang belum dikuasai oleh Raja, maka hal demikian berarti bahwa penguasa belum atau tidak lagi mempunyai kekuatan batin untuk mempersatukan segala kekuatan kosmis yang ada di dalam dirinya (Anderson, 1977: 13-19)

Cara seorang raja mendapatkan kekuasaannya sangat metaempiris, artinya bukan berasal dari sumbersumber yang dapat di lihat atau di raba, seperti harta kekayaan, keturunan maupun relasi. Sumber kekuasaan diperoleh dengan sebuah proses yang disebut laku, yaitu sebuah bentuk pengorbanan diri melalui ritual khusus untuk mencapai suatu tujuan. Sering terjadi melalui semacam pengalaman panggilan. Bisa saja dipanggil saat sedang bersemedi lalu dijatuhi semacam wahyu Ilahi, sehingga orang tersebut mendapat kekuatan adikodrati yang membuat wajahnya bersinar, hingga rakyat tahu bahwa tanda itu menyimbolkan kemunculan seorang pemimpin baru (Anderson, 1977: 16)

Membincangkan kekuasaan, maka bertalian dengan wilayah kekuasaan, seberapa luas tanah yang dikuasai sebe- 
sar itulah kekuasaan raja diakui. Arti tanah bagi manusia Jawa adalah perbincangan sebuah narasi yang merentang dalam sanubari spiritualitas dan etis, sekaligus menempati posisi yang demikian sakral jika melihat historiografi Jawa, dimana berpangkal pada kerajaan Pajang dan Mataram jadi titik tolak saat kuasa atas tanah demikian sakral, sebab kuasa sang Raja ditentukan oleh luas tanah. Corak inilah yang menjadi penanda khas dari kerajaan pedalaman Jawa, jika dibandingkan dengan gaya kepemimpinan para penguasa pesisir. Secara umum tanah menduduki posisi penting dalam kehidupan masyarakat agraris, karena diatas tanahlah terjadi kelangsungan hidup, sekaligus menumbuhkan kekayaan dan kekuasaan sebagaimana dianut oleh kehidupan feodal agraris. Menguasai tanah bermakna penguasaan faktor-faktor produksi lain yang menciptakan kekayaan dan kekuasaan, itu mengapa tanah sangat prestisius (Azis: 2013, Suhartono: 2001: 89)

\section{PRANATAMANGSA, THE LOCAL GE- NIUS SYSTEM}

Masyarakat tradisional mungkin tidak mengenal pendidikan formal, akan tetapi melalui alam mereka banyak mendapatkan pengetahuan. Pengetahuan tentang pertanda alam, perubahan musim, hama dan penyakit tanaman, di simpan dalam ingatan dan diwariskan kepada generasi berikutnya. Salah satunya adalah Pranata Mangsa, yang seringkali menjadi rujukan bukan saja bagi petani, tapi juga para nelayan maupun pemburu, dalam mengusahakan mata pencaharian mereka. Dengan memperhatikan perhitungan hari dan musim yang terdapat dalam Pranata Mangsa, diharapkan masyarakat dapat mengurangi resiko dan mencegah produksi biaya tinggi.

Masyarakat Jawa memang dikenal sebagai pendukung peradaban agraris yang sesuai dengan kondisi geografisnya. Pranata mangsa diperkenalkan pada masa Sunan Pakubuwana VII (raja Surakarta) dan mulai dipakai sejak 22 Juni 1856, dimaksudkan sebagai pedoman bagi para petani pada masa itu. Kehadiran pranata mangsa bagi masyarakat petani menjadi panduan penanaman padi pada waktu itu hanya berlangsung sekali setahun, diikuti oleh palawija atau padi gogo. Selain itu, pranata mangsa pada masa itu dimaksudkan sebagai petunjuk bagi pihakpihak terkait untuk mempersiapkan diri menghadapi bencana alam, mengingat teknologi prakiraan cuaca dan mitigasi bencana belum dikenal. Pada awalnya Pranata mangsa dalam bentuk "kumpulan pengetahuan" lisan tersebut hingga kini masih diterapkan oleh sekelompok orang dan sedikit banyak merupakan pengamatan terhadap gejalagejala alam. Baru setelah masuknya bangsa Eropa, para orientalis dan javanis menghimpunnya untuk kemudian disusun dalam bentuk pengetahuan yang tertulis, untuk kepentingan penelitian mereka.

Pranata mangsa merupakan satu contoh kearifan lokal dalam bidang pertanian. Menurut Ridwan (2007) kearifan lokal atau local wisdom dapat dipahami sebagai usaha manusia dengan menggunakan akal budinya (kognisi) untuk bertindak dan bersikap terhadap sesuatu, objek, atau peristiwa yang yang terjadi dalam ruang tertentu. Masih menurut Ridwan, secara substansial, kearifan lokal adalah nilai-nilai yang berlaku dalam suatu masyarakat. Nilainilai yang diyakini kebenarannya dan menjadi acuan dalam bertingkah laku sehari-hari masyarakat setempat. Hanya saja memang ada batasan ruang tertentu dalam pengertian kearifan lokal tadi. 
Pranata mangsa merupakan sekumpulan pengetahuan yang memang terbatas pada wilayah tertentu dan waktu tertentu. Pranatamangsa menyandarkan epistimologinya pada ilmu titen atau hasil kecermatan nenek moyang terhadap perubahan alam dikaitkan dengan berbagai aspek kehidupan yang dialami. Tanda yang dijadikan datangnya suatu mangsa atau musim sangat beragam, mulai dari perilaku hewan dan tumbuhan, gerak Matahari, curah hujan, hingga penampakan bintang tertentu di langit malam (Wahyudi \& Kurniawan, 2012).

Sindhunata (2011) dalam salah satu artikelnya tentang kecerdasan tradisional yang bernama Pranata Mangsa menyebutnya sebagai sebuah penemuan brilian. Kompleksitasnya tidak kalah bobot dari sistem penanggalan yang ditemukan bangsa Mesir Kuno, China, Maya, dan Burma. Lebihlebih jika dibandingkan dengan model Farming Almanac a la Amerika, Pranata Mangsa jauh lebih maju. Di dalam Pranata Mangsa, terdapat pertalian yang mengagumkan antara aspek-aspeknya yang bersifat kosmografis, bioklimatologis yang mendasari kehidupan sosialekonomi dan sosial-budaya masyarakat, ia mencerminkan ontologi menurut konsepsi Jawa serta stereotip alam pikiran Jawa yang dilukiskan dalam berbagai lambang yang berupa watak-watak Mangsa dalam peristilahan kosmologis yang mencerminkan harmoni antara manusia, kosmos, dan realitas. Pranata Mangsa pada dasarnya merefleksikan sikap hidup petani yang manyatu dengan alam (manunggal atau nyawiji). Alam bukanlah lawan yang harus ditaklukkan, bukan pula objek garapan yang diperas habis-habisan, juga bukan barang mati yang bisa diperlakukan sesuka hati. Alam tak lain adalah teman yang dicintai. Sikap hidup menyatu dengan alam itu membuat petani me- mahami watak dan perilaku alam. Kegembiraan alam adalah kegembiraan manusia, demikian pula sebaliknya, kesedihannya adalah kesedihan manusia juga.

\section{KONSTELASI ADIKUASA, KESE- JAHTERAAN DAN KESEIM - BANGAN ALAM}

Pembicaraan tentang konsep tersebut kemudian membawa perjalanan kepada pertemuan dengan konsep Hasta Brata, prinsip kepemimpinan Jawa ala Sultan Agung dalam Serat Sastra Gendhing maupun Serat Wulang Jaya Lengkara di satu sisi dan konsep kearifan lokal masyarakat agraris desa dalam Pranata Mangsa di sisi yang lain. Ada godaan untuk berasumsi bahwa Pranata Mangsa adalah sebuah bentuk "budaya tandingan" dari masyarakat desa yang tertindas secara struktural dan budaya di bawah dominasi kekuasaan elite birokrat yang ditempati oleh para Bangsawan penguasa. Posisi subordinat tersebut didasarkan pada kenyataan bahwa sesungguhnya dalam struktur kerajaan agraris, desa lah yang menjadi tumpuan utama keberlangsungan hidup dan kelanggengan kekuasaan yang berada diatasnya. Dan alih-alih memperjuangkan kesetaraannya, yang sudah pasti nisbi, masyarakat desa justru memproduksi semacam kearifan dan pengetahuan lokal (local wisdom and local knowledge) berbasis alam, Pranata Mang$s a$, yang justru makin mempermahfumkan posisi biner mereka.

Ada beberapa alasan mengapa rujukan yang muncul adalah asumsi kehadiran budaya tandingan, terutama pandangan dari sejarawan Kuntowijoyo (2006) dalam Raja, Priyayi dan Kawula. Pertama, cara kawula memahami simbol berbeda dengan priyayi, sebab ketika sampai kepada masyarakat bawah simbol meluntur seperti juga lunturnya 
produk-produk budaya yang lain. Berbeda dengan priyayi yang sehari-hari harus berhadapan dengan simbol, kawula hampir-hampir tidak berhadapan dengan simbol raja secara langsung. Tidak heran bahwa simbol-simbol kekuasaan Raja terasa sangat lemah. Terhadap priyayi-lah sehari-hari kawula berurusan dengan simbol. Kekuasaan raja dan perilaku priyayi itu menimbulkan hasrat untuk melawan secara diam-diam, lalu terbentuklah impian untuk melawan dalam bentuk budaya tandingan (Kuntowijoyo, 2006:13-14).

Ketidakmampun rakyat untuk melakukan perlawanan secara terbuka, seringkali disebabkan oleh kuatnya cengkraman struktural pemerintah, dalam hal ini kerajaan. Maka perlawanan yang lazim dimunculkan biasanya dalam bentuk ideologi, yang mewujud sebagai sikap hidup serta pilihan-pilihan keputusan yang kemudian diambil. Kedekatan kawula, dalam hal ini petani, dengan lingkungan budayanya mendorong petani untuk merekam berbagai pertanda alam, yang diyakini merupakan ikatan sebab akibat, dalam perutaran siklus yang tetap. Maka lahirlah ilmu titen, dari asal kata niteni yang berarti mengingat dalam rekaman memori. Dengan jalan niteni itulah, petani menjalani perannya secara profesional dan paripurna, sebagai pihak yang ditakdirkan sebagai penyangga pangan rakyat seluruh kerajaan, termasuk para priyayi sebagai patronnya, sebagaimana sejarawan Suhartono pernah menyinggungnya dengan menggunakan istilah wong tani kuwi panganing negari (Kuntowijoyo, 2001).

Petani pada umumnya telah mengenal waktu-waktu tertentu sepanjang tahun, yang tepat untuk melakukan satu jenis pekerjaan. Kapan waktu yang tepat untuk menyemai bibit, kapan masa dimana hama dan penyakit akan menyerang tanaman, hingga kapan saat yang tepat untuk menuai hasil panen. Ingatan-ingatan tentang pertanda alam yang kemudian dijadikan acuan kerja para petani disebut sebagai Pranata Mangsa.

Kedua, dengan ukuran keterlibatan budaya dalam kekuasaan, John Berkman dalam Culture and Domination (1987) menyatakan bahwa ada dua macam kebudayaan, yaitu kebudayaan afirmatif dan kebudayaan kritis. Sebuah kebudayaan disebut afirmatif bila ia mendukung kekuasaan dan menjadi alat dominasi. Sebaliknya, sebuah budaya disebut kritis bila ia menolak kekuasaan dan tidak mau menjadi alat dominasi (Kuntowijoyo, 2006:103).

Bila Hasta Brata, Serat Sastra Gendhing maupun Serat Wulang Jaya Lengkara berisi panduan menjadi Raja sekaligus cara melanggengkan kekuasaan dan sebagai alat untuk melegitimasi atas praktik eksploitasi terhadap rakyatnya, maka Pranata Mangsa juga menjadi panduan bagi petani dalam menjalani statusnya secara profesional. Dalam konteks ini, Pranata Mangsa menjadi budaya kritis atas dominasi kekuasaan para bangsawan. Pranata Mangsa menjadi semacam alat perlawanan yang elegan dari petani, untuk menunjukkan bahwa petani juga mempunyai local wisdom dan local genius. Pranata mangsa dapat dikatakan sebagai tradisi masyarakat agraris kuno, yang menurut sejarawan S.Margana, sayangnya tidak terdapat dalam rekaman maupun catatan resmi pemerintah tradisional, hingga para Orientalis Belanda menginginkannya. Lebih jauh S. Margana menyatakan ketidaksepakatannya atas anggapan bahwa pranata mangsa adalah formalisme budaya tandingan. Selanjutnya ia menambahkan bahwa, kehadiran sistem glebakan dalam sistem persewaan tanah di kerajaan oleh perkebunan Eropa berkontribusi terhadap kerusakan tradisi 
pranata mangsa (Margana: 2013).

Ketiga, kawula mempunyai jarak sosial-budaya dengan priyayi. Kawula mempunyai mentalitas tersendiri, karena simbol-simbol kekuasaan makin melemah setelah mengalami perjalanan sosial yang begitu jauh. Ada batas sosial -budaya yang tidak terjembatani, "priyayi adalah priyayi dan kawula adalah kawula". Di tengah kawula berkembanglah budaya tandingan yang memberi alternatif simbolis(Kuntowijoyo, 2006:122)

Diintrodusirnya sistem pertanian modern melalui kebijakan perkebunan dan tanam paksa memposisikan para Priyayi dan seluruh struktur ke-priyayiannya berada dalam barisan yang sama dengan pemerintah kolonial. Sementara para petani tidak mempunyai nilai tawar selain menjadi kuda beban, dalam statusnya sebagai penggarap. Lihat saja, bagaimana petani melakoni dua peran sekaligus, sebagai klien dalam struktur masyarakat tradisional yang terikat, tunduk dan patuh kepada patronnya, dan di saat yang sama menjadi buruh penggarap ditanah-tanah yang disewakan oleh para bangsawan kepada perusahaan perkebunan milik orang Eropa. Ironisnya, tidak banyak pembelaan yang dilakukan oleh para bangsawan sebagai pemilik tenaga kerja atas eksploitasi yang terjadi. Maka tidak heran bila ikatan-ikatan tradisional kemudian hanya bersifat formalitas belaka, dan jurang pemisah pun menjadi lebar. Apa yang bisa petani harapkan dari para patron yang tidak lagi melindungi.

Kondisi ini bukan tidak mungkin menjadi pencetus sikap-sikap perlawanan atau tindakan resistensi. Terlebih didodrong oleh kemunculan para elit baru yang lahir dari rahim pendidikan ala Barat. Kemunculan kelas baru dalam struktur masyarakat ini pun adalah hasil dari kearifan lokal yang bernama ngenger, sebagai upaya mobilitas vertikal yang dilakukan golongan petani demi memperbaiki kondisi sosial mereka (Suhartono:2001, Koentjaraningrat:1994) Ngenger memang bukan bentuk budaya kritis tapi juga tidak bisa dianggap afirmatif,ia adalah sebuah cara yang elegan yang mampu dilakukan kaum tani untuk melakukan perlawanan pada struktur kelas diatasnya. Ngenger menjadi sebuah alternatif untuk mensejajarkan diri melalui jalur akademik informal, karena meretas dominasi Trahing kusuma rembesing madu, sehingga status adoh ratu cedhak watu dapat diminimalisir.

\section{SIMPULAN}

Pemanfaatan Pranatamangsa ini ikut menyumbang pada keberhasilan dan keagungan kerajaan-kerajaan Mataram Lama, Pajang dan Mataram Islam. Dengan Pranatamangsa tersebut, orang pada zaman itu mempunyai pedoman yang jelas untuk bertani, berdagang, menjalankan pemerintahan dan kemiliteran. Pranatamangsa kiranya memperlihatkan suatu kekayaan, yang dalam khazanah ekologi disebut sebagai the spirituality of the earth, spiritualitas bumi. Spriritualitas bumi adalah spritualitas yang arahnya adalah penghomatan dan apresiasi pada bumi dan alam tempat manusia hidup dan berada.

Mengutip perenungan Sindhunata, seharusnya bumi tidak diperlakukan sebagai objek, tapi sebagai subjek. Bumi bahkan dianggap sebagai pertiwi atau ibu, yang melahirkan manusia dan memberikan apa yang kita butuhkan sehingga kita dapat berada seperti sekarang dan mempunyai apa yang kita miliki sekarang. Pranata mangsa juga menunjukkan, bahwa dalam totalitasnya, manusia tak bisa dilepaskan 
dari bumi. Menjadi manusia adalah membumi, mengalam. Karena itu manusia harus mengenal segala daya dan kekuatan alam, termasuk peredarannya yang berjalan dari musim ke musim. Pranatamangsa juga merupakan semacam ajaran tentang pengharapan. Di mangsa semplah, manusia memang dilanda putus asa, karena alam seakan tidak memberi rejeki padanya. Toh di sana manusia bertahan, karena begitu masa putus asa itu berlalu, datanglah mangsa pangarep-arep, yang akan memberi padanya kesejahteraan berlimpah-limpah. Pegangan untuk berharap ini mungkin akan tiada lagi, ketika pemanasan global terjadi dan menghancurkan perjalanan musim, yang selama ini ditangkap oleh petani sebagai perjalanan harapan manusia. Pranatamangsa adalah spiritualitas bumi yang radikal. Karena mempunyai spiritualitas ini, maka petani Jawa mempunyai kerohanian yang sekuat dan semurah bumi pula. Dalam spirituliatas inilah tersimpan rahasia, mengapa mereka yakin akan kepercayaan: Ana dina ana upo, ada hari ada nasi.

Pranata mangsa merupakan wujud harmonisasi hubungan antara manusia-lingkungan alam-dan Tuhan Yang Maha Esa. Keyakinan petani Jawa, dan masyarakat tradisional pada etnis lain, adalah bentuk keyakinan atas cara Tuhan bekerja mengatur alam melalui tanda-tanda alam, sebagai bagian dari keseimbangan kosmologis. Hukum alam bekerja untuk mengatur siklus iklim, perilaku hewan dan perlakuan manusia yang saling sesuai sehingga menghasilkan keseimbangan alam. Hukum alam itulah yang kemudian dibaca sebagai pranata mangsa. HAstha Brata dan Pranata mangsa adalah produk nyata dari bekerjanya sistem pengetahuan lokal yang tetap dapat bertahan dan nilainya masih sesuai dalam kehidupan saat ini dan masa depan. Se- bagaimana sebuah jargon iklan layanan masyarakat, local wisdom doesn't always belong to the past.

\section{DAFTAR PUSTAKA}

Anderson, Benedict. 1977. The Idea of Power in Javanese Culture, dalam Claire Holt, ed., Culture and Politic in Indonesia, Ithaca: Cornell Univercity.

-----. 2000. Kuasa Kata: Jelajah Budaya Politik di Indonesia. Yogyakarta: Mata Bangsa.

Antlov, Hans, Sven Cederroth (ed). 2001. Kepemimpinan Jawa: Perintah Alus dan Pemerintah Otoriter. Yogyakarta: Yayasan Obor Indonesia.

Arya Kresna, Aryaning. 2013. The Concept of Power and Democracy in Javanese Wo $r l d v i e w, \quad$ a $\mathrm{r} y-$ aning.aryakresna@surya.ac.id/ Ultima Humaniora, 10/ 2013 Vol. 1(2)

Berry, Thomas. 1990. "The Sprituality of the Earth" dalam Charles Birch, William Eakin \& Jay B. McDaniel (eds.). Liberating Life, Contemporary Approaches To Ecological Theology. Maryknoll.

Fidiyani, Rini, Ubaidillah Kamal. 2012. Penjabaran Hukum Alam Menurut Pikiran Orang Jawa Berdasar Pranata Mangsa, Jurnal Dinamika Hukum Vol. 12 no.3 September 2012

Husken, Frans, Benjamin White. 1989. Ekonomi Politik Pembangunan Pedesaan dan Struktur Agraria di Jawa, Majalah Prisma (4).

Kuntowijoyo. 2006. Raja, Priyayi dan Kawula. Yogyakarta: Penerbit Ombak.

Moedjanto, G. 1987. Konsep Kekuasaan Jawa, Penerapannya oleh Raja-Raja Mataram. Yogyakarta: Kanisius 1994. Kasultanan Yogyakarta dan Kadipaten Pakualaman. Yogyakarta: Kanisius.

2002. Suksesi dalam Sejarah Jawa. Yogyakarta: Penerbitan Universitas Sanata Dharma.

Munawir Aziz. 2013. Tanah dalam Kosmologi Jawa,http:// omahkendeng.org/201301/979/tanah-dalam-kosmologijawa/

Nawiyanto, S., Wasino. 2013. Kepemimpinan 
di Indonesia dalam Perspektif Sejarah dan Budaya. Yogyakarta: Laksbang Pressindo.

Ridwan, N.A. 2007. "Landasan Keilmuan Kearifan Lokal". Ibda' Jurnal Studi Islam dan BudayaVol.5 no 4.

Sindhunata. 2008. Ana Dina Ana Upa. Yogyakarta: Bentara Budaya.

2011. Pranata Mangsa, Jakarta: Kepustakaan Populer Gramedia bekerja sama dengan Bentara Budaya.

Suhartono. 2011. Serpihan Budaya Feodal. Yogyakarta: Agastya Media
Sulistyowati. 2012. "Hasta Brata Ajaran Kepemimpinan Jawa Masih Relevan di Era Global" Majalah Forum, vol. 40 (2), Oktober.

Wahyudi, M.Z. Al.Budi Kurniawan. 2012. Pranatamangsa Menjaga Titen Leluhur. $\mathrm{D}$ a $\mathrm{l}$ a $\mathrm{m} \quad \underline{\mathrm{h}} \mathrm{t} \mathrm{p}: / /$ omahkendeng.org/2012-12/772/ Pranatamangsa-menjaga-titenleluhur/

Wiriadiwangsa, Dedik. 2005."Pranata Mangsa Masih Penting untuk Pertanian". Tabloid Sinar Tani Edisi 9-15 Maret. 